\title{
Remembering Arnold Picot
}

\author{
Rolf T. Wigand ${ }^{1,2,3}$
}

Received: 23 August 2017 / Accepted: 23 August 2017 / Published online: 14 September 2017

(C) Institute of Applied Informatics at University of Leipzig 2017

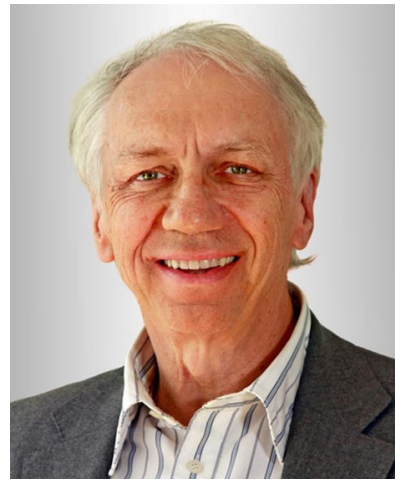

Our friend, colleague and collaborator Arnold Picot passed away on Sunday, July 9th, 2017 while jogging at the young age of only 72 years. Arnold was born in Gmunden, Austria, in 1944. He is survived by his wife, Sibylle, and two daughters (one a psychologist and one a medical doctor, both in Berlin) and a son (a professor at the University of Bergen in the Department of Comparative Politics).

The memory of good friends, former colleagues and professors makes us reflect on how we relate to people. Our

Rolf T. Wigand

rtwigand@ualr.edu; http://www.ualr.edu/rtwigand

1 Department of Information Science, University of Arkansas at Little Rock, Little Rock, AR 72204-1099, USA

2 Department of Management, University of Arkansas at Little Rock, 548 EIT Building, 2801 South University Avenue, Little Rock, AR 72204-1099, USA

3 Emeritus College, Arizona State University, Old Main 102, Tempe, AZ 85287-3002, USA relationships and connections with Arnold and to each other remain indelibly imprinted in our memories and are timeless. There are people who pass through our life; there are also those who set up camp. Arnold was one of those people who set up camp and he will continue to have a presence and a special place in this camp in our hearts.

Arnold Picot, the venerable Ludwig-Maximilian University of Munich (LMU) educator and distinguished scholar, was a German economist, professor of Business Administration and Director of the Institute for Information, Organization and Management. His research and contributions were also well known in the fields of organization theory, communication, organization structure, telecommunication regulatory processes and electronic markets. Arnold was an internationally and widely esteemed scholar with numerous academic awards and honors. He was indeed a prolific researcher and writer with countless published scientific articles. Arnold produced a shelf of over 90 books to his credit either written or edited by him. Major contributions can be identified in the areas of transaction cost analysis and theory, and his research focused on the interdependencies between information and communication technologies and structures of organizations and markets. He has published numerous books and articles dealing with information and communication management and the evolution of strategies and organizational forms, including topics such as office communication, electronic data interchange, telecommunications, electronic markets, virtual organization, and regulation.

Arnold studied business administration at the LMU. There he also completed his requirements for his dissertation and habilitation. After professorships at the University of Hannover and the Technical University of Munich (TUM) he moved to the LMU Munich in 1988. Here he directed the Institute for Information, Organization and Management for over 25 years right 
to the time he became professor emeritus. He developed the Institute to become a renowned and well-respected international research institution. Parallel to these efforts he led the Münchner Kreis, the leading international and independent platform providing orientation for decision makers in the digital world, from 1999 to 2013. Among the topics he initiated there were smart business networks in November 2012. In addition, Arnold served with the pharma and laboratory supplier Sartorius in Göttingen as a member of the supervisory board and later on as chairman of the supervisory board. Arnold directed the University Council at the University of Hannover for many years right to his untimely death.

Arnold received honorary doctorates from the Bergakademie Freiberg and the University of St. Gallen. Visiting professorships led him to Stanford University, Georgetown University (Konrad Adenauer Visiting Professor) and the University of Strasbourg. Invitations/calls to the Free University of Berlin (1984), the universities of Bern (1987), St. Gallen (1989) and Vienna (1994) he turned down. In 1999 Arnold was elected as a regular member of the Bavarian Academy of Sciences where he also served as vice president.

I first met Arnold in a phone call on an National Science Foundation (NSF) grant with my former professor, Ev Rogers, still at Stanford University at the time. Toward the end of that call, Ev told me that he had a visitor from Germany in his office with whom I had a lot in common. He passed the phone to Arnold and we chatted for two hours. Two days later I visited with Arnold for more intensive discussions. A few months later Ralf Reichwald joined us. This is how our friendship and collaboration for over 42 years started and thrived, despite 10 books and various other projects for the Alexander von Humboldt Foundation, the German National Science Foundation, the NSF and the Volkswagen Foundation. Arnold and I were both grateful to Ev Rogers enabling this connection and giving impetus for a strong future personal friendship.

Key among our book projects was Die grenzenlose Unternehmung: Information, Organisation und Management (1996-2005 in nine editions, plus translations in English (Wiley, 1997, 2000) and Springer (2008) and Japanese (Zeimu Keiti Kyokai, 2000, 2003)). All issues and editions were together among the three of us, i.e. with our good friend and collaborator Ralf Reichwald. The effort became a transatlantic labor of love, our friendships thrived lasting to today, despite the occasional challenges and race toward impending deadlines.

Die grenzenlose Unternehmung was listed among the " 75 Best Management Books of All Time" in the Handelsblatt Management Bibliothek, Vol. 1, pp. 188-192, Campus Verlag, Frankfurt and New York, 2005; Handelsblatt, 2005;
Picot et al. 1966; Picot et al. 2000; Picot et al. 2008; Römer et al. 2015; Wigand et al. 1997. The same publication lists the book also among the best book contributions during the same 75 year time frame under the rubrics or topics of: Leadership and Organization, Marketing and Distribution, Economics. The Wiley editions were listed as a recommended selection as a Best Business Book in the Forbes Book Club by Forbes Magazine, 1997 to present.

Arnold has also been a long-time contributor for the Electronic Markets journal. He has been a member of the Electronic Markets' editorial board since 1999 and until recently, he has not only been an active reviewer, but he has also authored a research paper in the second issue of 2015. In this special issue on smart energy he was presenting research on distributed electricity storage systems titled "Smart Energy for Robinson Crusoe". He and his co-authors saw the upcoming of decentralized energy systems and aimed to better understand the diffusion of such storage systems. The article proposed factors that are necessary for the acceptance and adoption in private households. Similar to transaction cost economics, questions on decentralized energy are still relevant issues. For sure, Arnold has also influenced many authors, readers and board members of Electronic Markets with his thinking as well.

Arnold loved visiting the Southwest of the United States. While visiting, he jogged daily in the desert as the first sunlight arose. He loved the big blues skies as well as drawings by Georgia O'Keefe depicting these marvelous skies. During these visits, we often had lengthy and endless discussions on Adam Smith, Ronald Coase, Friedrich August von Hayek, Oliver Williamson and Tom Malone and planning new projects. During lunch and dinner stops Arnold showed his fondness for American apple pie with vanilla ice cream as well as Southwestern and Mexican food, not necessarily in that order.

It is indeed painful to realize that Arnold is no longer with us. Many students described Arnold as a wonderful, nourishing and innovative mentor and smart adviser. We all admired his visionary insight and capacity as well as his always multidisciplinary curiosity. Appreciative accolades as well as rituals lacking in content and substance he did not care for. What I remember most fondly about Arnold is his unassuming and personable demeanor and style, his humanity and kindness as well as his love of life, true joie de vivre, which he expressed with exuberance and verve. Even though our paths parted in a sense when Arnold left us, he continues to be our timeless role model, adviser, academic father-figure and good friend. Arnold thus will always be with us.

This is how I would like to remember Arnold Picot: He was indeed a dear and close friend and a prince of a man.

I will always be thankful that I had the opportunity to get to know him better and to call him a friend. I will cherish his memory.

\section{Rolf Wigand}




\section{References}

Handelsblatt. (2005) 75 best management books of all time. In Handelsblatt Management Bibliothek, Vol. 1, pp. 188-192. Frankfurt: Campus Verlag.

Picot, A., Reichwald, R., \& Wigand, R. T. (1996, 1997, 1998, 2001, 2002, 2003 and 2005). Die grenzenlose Unternehmung: Information, Organisation und Management [first, second, third, fourth and fifth editions], Wiesbaden: Gabler Verlag.

Picot, A., Reichwald, R., \& Wigand, R. T. (2000 and 2003). Information, organization and management: Expanding markets and corporate boundaries, [in Japanese] Tokyo: Zeimu Keiti Kyokai.
Picot, A., Reichwald, R., \& Wigand, R. T. (2008) Information, organization and management. Berlin: Springer Verlag (http://link.springer. com/book/10.1007/978-3-540-71395-1/page/1).

Römer, B., Reichhart, P., \& Picot, A. (2015). Smart energy for Robinson Crusoe: an empirical analysis of the adoption of IS-enhanced electricity storage systems. Electronic Markets, 25(1), 47-60. https:// doi.org/10.1007/s12525-014-0167-5.

Wigand, R. T., Picot, A., \& Reichwald, R. (1997 and 2000). Information, organization and management: Expanding markets and corporate boundaries. Chichester: Wiley. 